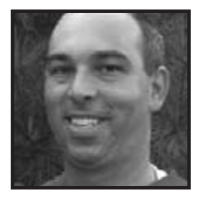

\title{
Who Put You in Charge? Democracy in a Middle School Classroom
}

\author{
Matthew McCarney, Selwyn House School
}

\section{ABSTRACT (Press Here for Sound)}

In this article three strategies are examined for their efficacy in the implementation of a democratic classroom environment. The first is modeled on ancient Athenian democracy, the second employs a Class Council, and the third uses a Class Committee. The author implemented these three strategies with a group of twenty grade seven boys in an effort to increase their engagement in the day-to-day running of their classroom. The students in question rise to the occasion and become fully committed participants.

\section{Reflective Interview With Matthew McCarney}

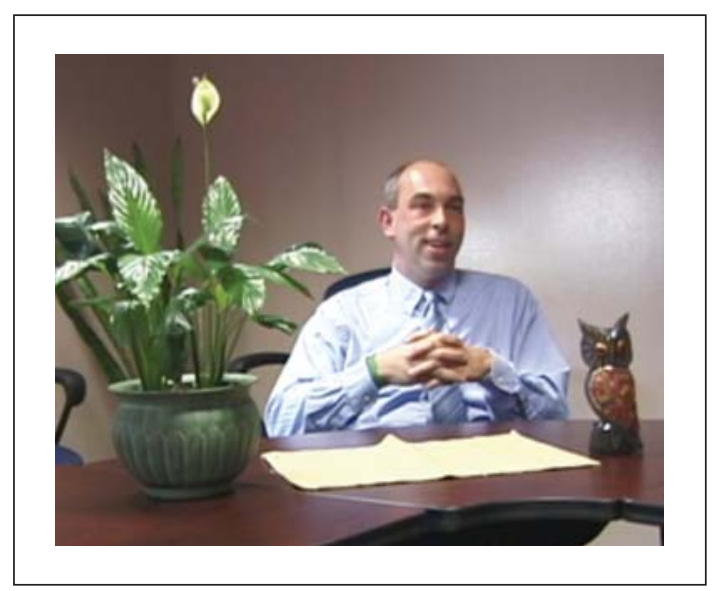

(Press here to see and hear Matthew.) 


\section{My Democratic Experience}

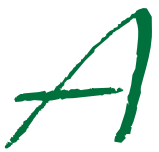

s I brainstormed ideas for my Master's project, I found myself reflecting on the type of school environment in which I had grown up. My high school experience took place in a co-educational Catholic school run by the Grey Sisters. My teachers were a mix of nuns and lay people, and, the nuns were open to discussion and suggestion. As members of the student council, we were given a tremendous amount of autonomy in the running of activities and a great deal of say in the direction of the school. The student body was informed of major decisions and we were asked for our input. It was empowering to be part of a school like that. We were a small school. We did well in many areas, but we did not excel in any particular one. The student body as a whole, however, was fully engaged in the life of the school. We held monthly dances that everyone attended. We fund-raised for various charities and everyone participated. We cheered on our sports teams regardless of their record. This broad engagement in school life stemmed from, in my opinion, the fact that we were consulted and made aware of the decisions facing our school. We did not always have a say, but we were definitely aware of what was transpiring.

My first teaching job was in a similar school. Our principal was there to provide guidance to his staff, but he trusted us with the stewardship of our classes. He was positive and engaging, and he worked hard to create a school culture that was similar to the one in which I had grown up. It was logical to me upon reflection that I should look at a way to create a similar culture in my current school. With the focus on student led-conferences, and a proactive approach to student learning that comes with the Quebec Education Program, I thought that the best way to achieve this was to implement a democratic classroom environment in my grade seven class.

\section{Why Educate for Democracy?}

Schools fulfill a multitude of needs in our modern society. At their most basic level, they serve to educate the population in a variety of subjects such as English, history, science, mathematics and others. But schools also play an important role in socializing our children. It is in schools that children learn how to interact, how to speak, and how to work with others. In their book, Toward Schooling for the Twentyfirst Century, Dalin and Rust (1996) focus on schools educating students to be democratic citizens of the world. "They [schools] must be the arena where different children learn to get along, to resolve differences, and debate points of view" (p. 104). Henry Giroux (1993) further explains the idea that we should educate students to be democratic citizens. 
At issue here is recognizing that democracy is not merely about the formality of voting but more substantively about having access to the technological and cultural resources necessary to be informed, make decisions, and exercise control over the material and ideological forces that govern people's lives. (p. 12)

These concepts were key to my project. Far too often students are passive vessels in the classroom environment. If there is conflict, I want them to be able to see each other's point of view and be able to come to a mutual understanding that is not imposed by me as a teacher. They are far better served being able to solve their own problems. Sadly, too many teachers adhere to the old ideal that students are young and/or immature and unable to do so for themselves. I would argue that given the tools and skills they need, students would not only be able to solve their own problems, but would also relish the opportunity.

Too often teachers teach as they were taught. As Rothstein (1996) writes in Schools and Society:

... students sit at their desks and interact with their teachers; who are located in the front of the room. Teachers are typically adults who have been trained and certified in a university. Teachers choose the materials and methods for the students' work in-class, assuming their need for instruction in these areas. Teachers are more mature physically and have greater experience, competency, and status than their students. Nevertheless the authority is derived from their appointment to a teaching position in the school bureaucracy. They lead as a consequence of this organizational role, following behaviour patterns that have been developed over many years. Teachers are the instructional leaders of the class, and their status and charisma are attached to their rank as a teacher, and not to any particular qualities they may possess. (p. 107)

Rothstein has accurately depicted the traditional example of teaching. Teachers are given authority and are told to provide direction on the basis of their apparent superior understanding of the needs of students. I would argue that who knows the students' needs better than the students themselves? Their voices should be heard and considered when engaging in curriculum design or decision making that affects them directly. There needs to be a paradigm shift in our view of the purpose of school. We are not merely here to impart knowledge to the students, but rather to help them learn how to think, how to be productive, and how to work 
together. In addition, there is a moral and social component to our job. We must be models of moral and ethical behaviors for our students. That is not to say that we no longer have to fulfill the role of imparter of knowledge. We do. It should not be our central role though. "Sometimes teachers were still disseminators of information, but more often we were learners as well as facilitators of learning" (Apple \& Beane, 1995, p. 98).

As Ken Osborne (2001) writes:

A democratic liberal education consists not of stockpiling the knowledge of the past, an approach that Paolo Freire condemned as a "banking" concept of education in which students amass knowledge / capital for later use, but of using knowledge to evaluate and participate in the life of the present with the aim of shaping the future. (Portelli \& Solomon, 2001, p. 44)

Democratic classrooms move away from the traditional view of the classroom that Rothstein describes. In a democratic classroom, all the students can be authority figures. At its core, a democratic classroom is a student-oriented, open learning environment that allows students to engage in shared leadership. The students take ownership for their behaviour, their classroom, and their learning, which will hopefully increase their engagement in the school. Increasing their engagement and empowering them to be autonomous will give them the tools to engage in that shaping of knowledge that Osborne describes.

One of the key facets in democratic classrooms and education for democracy is engaging in shared leadership. The students are expected to participate in all aspects of the class, and they should therefore be given a say in how it is run, how rules are established, how discipline is meted out, and how conflicts are resolved. In a democratic classroom, the teachers also participate in the activities alongside the students. In doing so, the teacher is removed from being a power figure in the class, and instead becomes one of the members of the class. The decision-making power can then be shared among all the members of the group, and everyone benefits as a result. The teacher does remain an authority figure based on his/her expertise in his/her particular subject area. The teacher remains a facilitator with regards to the curriculum, but shares the decision-making power with the students in order that their best interests be served. By engaging in this shared leadership the teacher can help empower the students. In his essay entitled, Democracy, Democratic Citizenship and Education, Ken Osborne (2001) explains the importance of teachers engaging in the process and activities alongside their students: 
What matters is not so much whether the teachers use this technique or that technique, but whether they deliberately espouse democratic citizenship, with all its implications and possibilities, as a fundamental goal and organize their subject matter, their pedagogy, and their classrooms to attain it. (Portelli \& Solomon, 2001, p. 47)

There are arguments that some critics of democratic classrooms bring up when discussing the topic. Some argue that students are not capable of engaging in these types of activities. Some teachers who fear the shift in power might say that allowing students to engage in the decision making would open the door to chaos. I would argue that students have the ability to be active, engaged learners, and they only need to have an opportunity to rise to the occasion. True, some lack the maturity to be serious when engaging in shared decision making, but if the bulk of the students are participating and participating well, they will eventually regulate the situation themselves. The students, along with the teacher, can exert some positive peer pressure to bring the noncompliant students into the fold. Often it is the most "troublesome" students who are quickest to buy in to the democratic schooling model. I am a firm believer in the Pygmalion effect. ${ }^{1}$ If we believe that the students are capable of doing it, then they themselves will believe that they are capable.

Democratic classrooms may start out as just that, classrooms, but the ramifications they have for society are tremendous. If students can realize that the skills they learn in a democratic classroom can be extrapolated and applied to their daily lives outside of school, then teachers have taken a tremendous step towards educating our students to become better citizens and better people. Students will have the necessary skills to participate more fully in our democratic society. Learning collaborative skills and taking ownership of their decision making may enable them to be proactive rather than reactive when it comes to participating in our society at large.

In their book, Pockets of Hope, De los Reyes and Gozemba (2002) provide a case study of McDowell County, West Virginia that engaged in a democratic education program on several different fronts simultaneously. The authors worked in the high school as well as with the various communities in McDowell County, which was one of the poorest counties in the United States at the time and was experiencing a tremendous feeling of disenfranchisement. McDowell County had been a mining centre for many years, but in the recent past its economy had declined and businesses had left the region, leaving it in a devastated state. It is a thought-provoking case study that shows how it is never too late to engage in education for democracy. Helen Lewis was the community educator that worked with the people of Ivanhoe, 
West Virginia, and she worked diligently to empower them to understand their role in democracy.

The people of Ivanhoe, like millions of Americans, had always imagined themselves practicing democracy through the simple act of voting. ... Not until they tried to bring about change in their community did the people fully understand that they had long ago ceded their power to others. (p. 187)

As they began to motivate and mobilize themselves to bring about change in their community through the democratic process, one participant articulated this change in outlook. "We have been on a train for the last hundred years and we rode as passengers. And now we're not passengers; we're engineers" (p. 187).

\section{The Democratic Classroom Project}

I teach in a private boy's school, and I engaged in a democratic classroom project with my 20 grade seven students. ${ }^{2}$ I see them roughly twice daily for English and History class. The project was begun in April 2008, and the boys had been together in the same class since September 2007. This circumvented the need to do icebreaker activities with the boys. They already knew their peers and were quite comfortable with them and myself. Had I begun the project in September, some initial team-building activities would have proven beneficial. As it was, I chose to proceed with the status quo.

There are many variations on the ideas for creating a democratic classroom environment. For the purposes of this project, I focused my attention on three particular strategies. Each strategy was scheduled to last for two weeks. The first one was modeled after ancient Athenian democracy where every citizen had a say by virtue of the fact that he was a member of Athenian society. The students were already familiar with this method from their time in history class. When studying Greece, we engaged in an interactive simulation of Greek society, and one of the units was on Athenian democracy where students debated issues such as slavery, Persian invasions, the rights of women, etcetera and each person had a vote. For our purposes, each of us in the class, myself included, had one vote by virtue of the fact that we were citizens of our class.

The second strategy was that of using a Class Council. The boys were randomly divided into five groups of four. Each group elected/chose one member of its group to represent its interests on the Class Council. There were designated meeting 
times where each representative could sit down with his constituents and discuss issues that confronted them. The Class Council was given time to meet in the school's conference room to discuss the issues at hand. The boys then presented our decisions to the class as a whole.

The third strategy was the Class Committee approach whereby the boys chose one of five committees to sit on. The five committees were: discipline, teacher liaison, curriculum planning, classroom management, and mentoring. Specific meeting time was set aside for the committees to meet and discuss how they could impact the working of the class. The committees rotated their locations so that the same group was not always in the school's conference room. Some went to the library or to empty classrooms, or they stayed in our classroom. Some committees, such as discipline, met more often as they had issues that had to be dealt with nearly every day.

My goal in using these three strategies was to see if one was more effective than the others and also to see if there were elements arising from the different strategies that could be effectively combined together. My students had more than a passing experience with democracy in the classroom. I often allow for some informal choice opportunities in the day-to-day running of the class. Students have been allowed to choose "mental health days," where we focus on things other than schoolwork, and they have also been able to move assignment due dates if they are stressed or overworked.

On the whole, the boys were excited at the prospect of making decisions that impacted their class time. After explaining the project to them, they were eager to begin. One notable dissenter was Eric B. ${ }^{3} \mathrm{His}$ body language indicated that he was not eager to participate. When I asked him why, he replied that he felt he was lazy and would not be able to govern himself effectively. He did not want to choose the path of least resistance and cheat himself of a good education. This was frustrating to me as he absolved himself of all responsibility and placed it squarely in my hands. It is notable that he was the lone dissenter. In discussions with colleagues and administrators, most feel that Eric B's attitude would be prevalent in a democratic classroom; the students would choose the path of least resistance and take the easy road. Initially I argued against them and when the project was completed, my theory was validated. The boys rose to the occasion and engaged fully in every activity. Eric B. eventually did participate in the majority of the activities but he remained skeptical. He voiced his reticence to participate even as he was doing so. Often it was clear from his body language that he was enjoying the class. This proved problematic to his peers and left me with questions as he was clearly enjoying being a part of the 
project. One wonders if he enjoyed being contentious or if he truly rejected that it could make a difference in his academic life.

We engaged in one initial 75-minute class discussion and brainstorming activity where we discussed what democracy meant, what someone's responsibilities were in a democracy, and how and why we could effect change. We shared our ideas in small groups and then brought them together in a large group plenary session. Everyone agreed that participation and listening to each other's opinions were key elements. We agreed that being a citizen in a democracy meant that you had both rights and responsibilities. These were listed on the board and included the responsibility to share decision making, participate fully, and share thoughts and opinions. During these discussions I was surprised at the number of students who felt that they lacked the ability to effect change. Quite a few said that they were too young, or lacked life experience to make a good decision. Some said it was better for the teachers to make the decisions for them. I told them that I could see their point, but it had been twenty three years since I had been a grade seven student, and while I have taught grade seven for ten years, I suggested that they know better than I do the challenges they face every day in 2008. They seemed to understand that. I did not want them to feel that they could not effect change or that the decisions they made in the project were simply for the purpose of the project itself. I explained to them that the strategies that worked in the project might find their way into classes in our Middle School in the future.

For the first strategy, Athenian Democracy, the boys were divided randomly into groups and we brainstormed what was involved in the running of the class. When it came time to share with the large group, they looked to me to run the discussion but I held back. Two students quickly moved to the front of the room, and began to write down the ideas that the class had come up with. It was mildly chaotic to start, but the boys quickly sorted themselves out and decided that they had to take turns talking. 


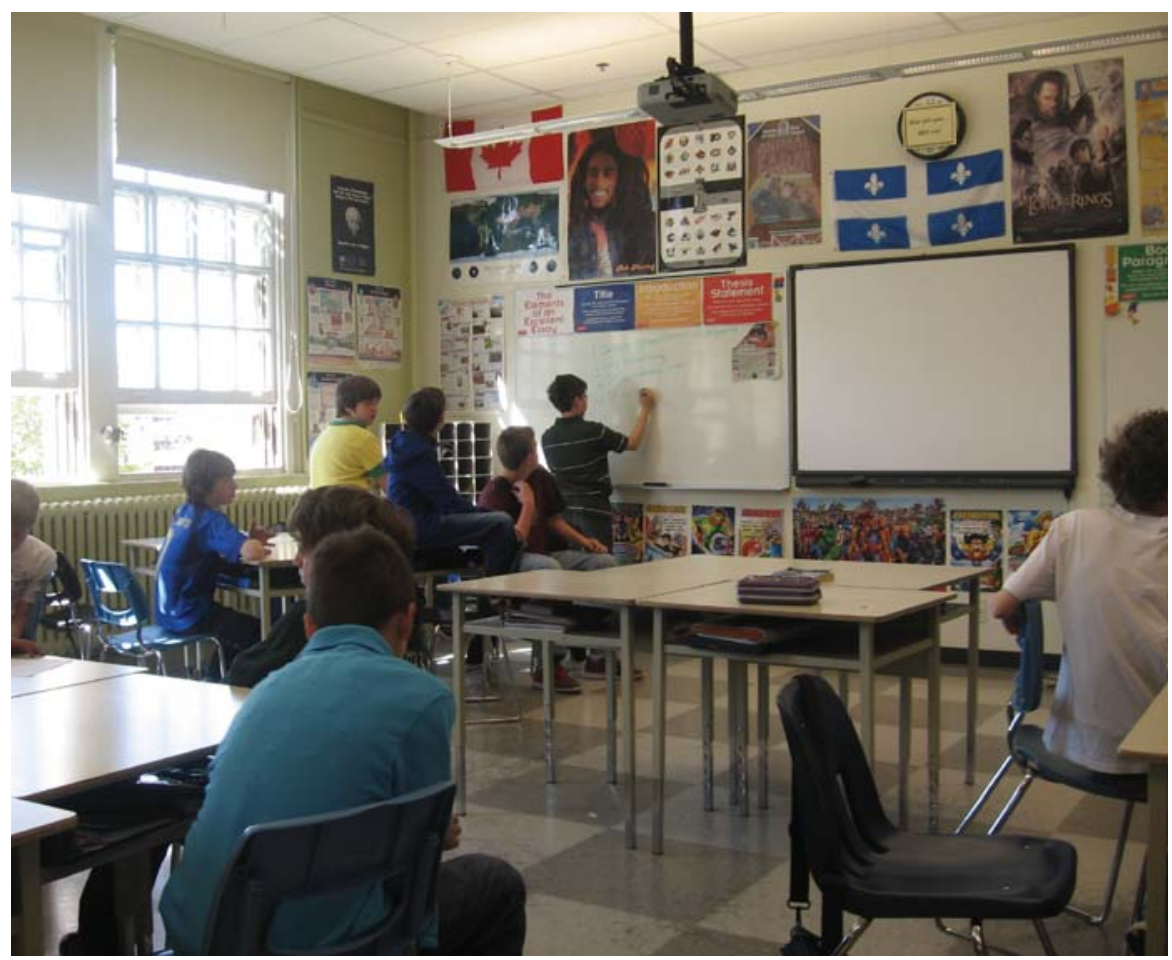

Fig. 1: List of items involved in running our classroom

Adam referred to it jokingly afterwards as "controlled anarchy." At the end of the class, the boys had come up with a concrete list of what was involved in the running of our classroom.

The next class involved the boys working in different randomized groups again, and deciding on five rules for our classroom, and the consequences that should be applied if someone broke a rule. The students took to this activity and there was a great deal of debate and discussion over which five rules would be most appropriate. A final list was generated by the class as a whole and we all signed off on it. For the remaining week and a half we used the Athenian Democracy method to decide upon our course of study, what consequences to impose on those who broke rules, and what to do when. The boys felt empowered during this time, and there were fewer instances of forgotten work. They participated fully and the stress level seemed to decrease as they were able to shuffle some due dates to accommodate other classes. One drawback was the fact that the discussion often consumed a great deal of time as the various opinions were debated. While we did get better by 
the end of the two weeks, these discussions continue to consume roughly one fifth of our class time.

With the conclusion of the Athenian democratic model, we were ready to move on to the second strategy: the Class Council. The Class Council essentially consisted of establishing a representative democracy in our classroom. I began this portion of the project with a mini-lecture on representational democracy. We examined what a representative democracy entails, what people's roles are, and I explained the idea of constituents and the importance of representing other people's interests fairly. Again, I was impressed with the students' background knowledge of democracy and democratic structures. They were willing to discuss the concepts at length, and they were often quite familiar with the terms I used.

I randomly arranged the boys into five groups of four. Names were pulled from a jar in order to ensure complete randomization. I did this because often in grouping students, they feel that I have some sort of secret agenda. I am almost always asked if the groupings were really random or if I had manipulated them somehow. In order for the students to know I was being fair and honest, I pulled the names in front of them. Again, this appealed to their sense of fairness. Once they were situated in their new groups of four, I provided them with a very brief outline of what this section of the project would entail. Each group of four would elect a representative to the Class Council. As a group we brainstormed a list of how people could possibly choose leaders. The students all mentioned voting and electing people, but they were also well acquainted with strong-arm tactics, and they got quite creative with their bribery and threat scenarios. Initially I was going to instruct each group to vote for its representative, but after the brainstorming session I wanted to see how each group would respond. I told them the students had free rein to elect/choose their representative in whatever fashion they chose. Would anyone decide to strong arm their way onto the Council?

We set a ten-minute time limit to engage in initial discussions. If the students needed more time afterwards, we decided rethink our timeframe. The discussions were animated and excited from the outset. Only one group remained seated, and the other four leaned towards each other and raised their voices. While they were not shouting, they were definitely speaking forcefully to each other, and the debates were fast and furious.

After ten minutes three of the five groups had chosen their representative, so we allowed a few extra minutes for the two other groups. Their methods of selection 
included voting, pulling names from a hat, and flipping a coin to decide who their representative would be. Once the groups had all chosen their representatives we moved on to the next phase of the project. The five representatives came with me to the conference room down the hall. I provided them with markers, chart paper, and anything else they requested. I told them that aside from the rules that we had decided on together, and the fact that we had to study the novella, OfMice and Men, they were free to change or do whatever they wanted with regards to the class. I left them alone in the conference room and told them that they should come back to the class in roughly twenty minutes to share their decisions with the rest of the class. I observed them informally for a few minutes from the other side of the door, and they got right to work. They used the easel and markers and began to jot down ideas. Afterwards they told me that they wanted to have a written record of what had been said in order to share it with the rest of the class.

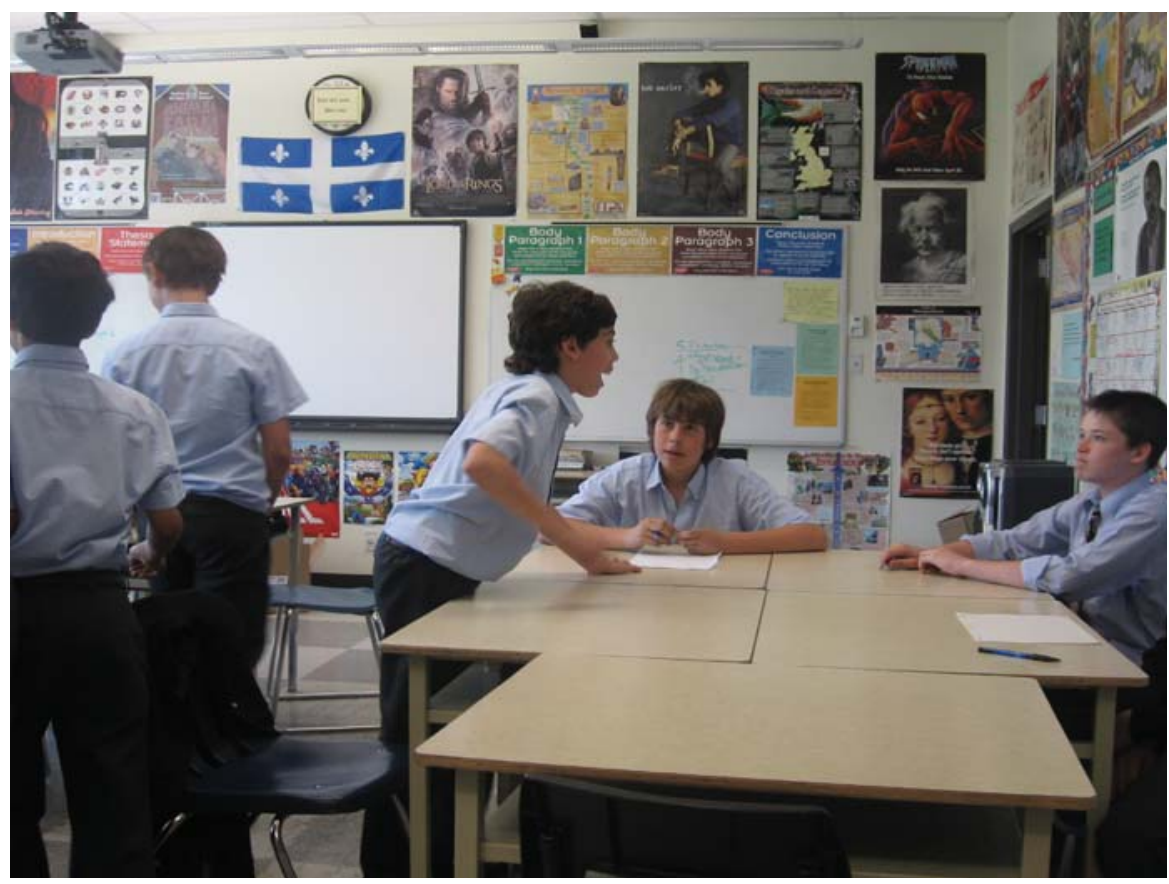

Fig. 2: Lester trying to persuade his group to elect him as its representative

While the Class Council planned the coming two weeks, I returned to the class and gave each group a sheet entitled Representative Democracy and asked the students to answer the three questions. The first was straightforward as it asked for the name of their group's representative. The second dealt with how they chose their 
representative, and the third question asked why they chose him. Taking their cue from my grouping of the class, two of the five groups picked their leader out of a hat. Three of the five groups voted for their representative but then ran into trouble. Those three groups found themselves deadlocked between two candidates. Two groups chose to flip a coin to break the tie between the two candidates, while the other had someone write a number on a piece of paper and the one who came closest won. Oddly enough everyone seemed happy with the outcome in these cases. I was surprised that they were so willing to put their faith in chance.

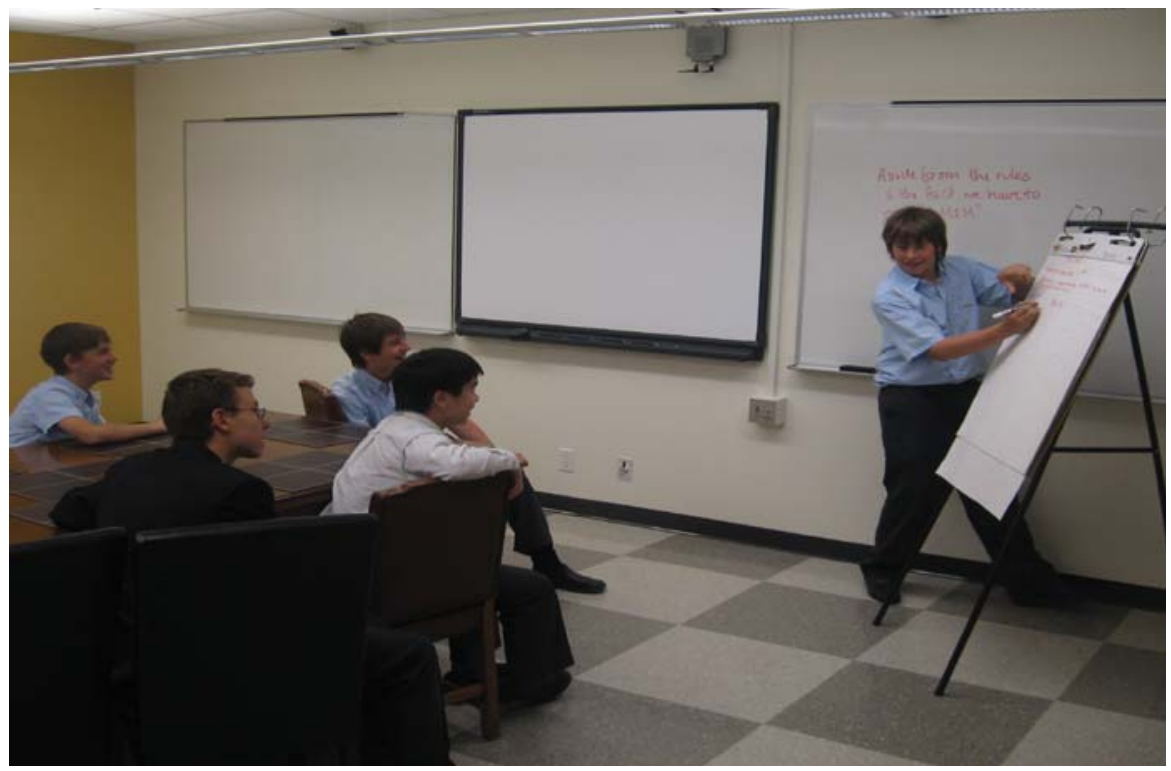

Fig. 3: Members of the Class Council establishing classroom practices

What strikes me as interesting is that in all five cases the student chosen by the groups to be their representative is the same one I would have chosen had the decision been up to me, even in the four cases where they left the final decision up to chance. The Class Council consisted of Francis, Nathan, Aaron, David, and Andrew. All five were top students in the class, and respected by their peers. They are friendly, warm, and open, and they are also good listeners. Aaron's group said this about him: "Aaron is very responsible. He has very good judgment. He represents with pride and responsibility." Andrew was chosen because:"... we knew he was pretty smart and that he'd make the right decisions. We also chose him because he wasn't stupid." As I said, the final decision was often luck of the draw but the best candidates won, and everyone was quite content with the final decisions. 
The Class Council proved to be quite responsible. The Council met with its constituents for 5-10 minutes at the beginning of each class and listened to their concerns. At the end of the class the Council took another 5-10 minutes to meet together, discuss issues, and make changes if it felt it necessary. The five-minute meetings were easy to accommodate as it took only the first few minutes of the class. Allowing the boys to feel like their ideas and concerns were being heard seemed to set them at ease during the class, and we had fewer discipline issues during that time. There was also far less complaining about the test dates, due dates, and the detentions since they were coming from their peers rather than from me. This strategy was labor intensive at the beginning but was much quicker and smoother as time went on. We concluded the two weeks with a roundtable debriefing and two main ideas came out of this. The first one was that the students felt that their ideas were being listened to and appreciated more. The second was that they would all have liked a chance to sit on the Council, and they recommended that Council membership be changed on a monthly or bi-monthly basis. Even Eric B., the initial dissenter, was eager to sit on the Council.

The third phase of the project was governing the class by committees. Five committees were established: The Discipline Committee (DC) dealt with issues of discipline and individuals breaking the six rules we created as a class. The Curriculum Planning Committee (CPC) dealt with curriculum planning and areas of study. The Mentoring Committee (MC) served as a group of boys to go to if there was a particular concern about anything in the class. They could offer advice or be our advocate if need be. The Teacher Liaison Committee (TLC) worked with me. Its mandate was to present student concerns to me and to relay any concerns/issues I have. The Classroom Management Committee (CMC) was responsible for the daily management of our physical space (i.e., tidying the class, taking care of recycling, etcetera). These five committees had four members each. I circulated a sheet to each student, outlining the committees and their responsibilities, and asked them to choose three that on which they would like to serve. These committees and their responsibilities had been decided upon by me in advance of the project. This was largely due to time constraints. Ideally students should work in conjunction with the teacher and establish which committees are needed in the particular class and what their responsibilities should be.

Luckily for me all members of the class had volunteered for every committee. Some students got their second or third choice, but they were all given something they wanted. I had grouped them in their committees and then created four subgroups of five which contained a member from each of the five committees. I 
often use this idea in my history courses. I have the students engage in a jigsaw where they are in an initial group of four or five students who then break apart to become experts in a particular area. These experts in the field then team up with similar experts from other groups. They work together to find as much information as they can and then return to their initial groups to teach their initial group in their area of expertise. The reasoning behind doing this was that each committee should meet and come to decisions or put forth ideas. The committee members could then return to their subgroups, which would contain a member of each of the other committees, and report back to them.

With fifteen minutes remaining in each class the students generally came together in their committees. They were urged to think about issues that faced their committee and what they could do about them. The Classroom Management Committee started to work right away and straightened up the classroom. The Discipline Committee often had issues to deal with. The students would often retire to the hall where they dealt with these issues. Initially the other three committees told me that they could not think of what they needed to do, so I circulated and spoke to each one.I sat with the Mentoring Committee and urged its members to talk to the students informally and see if anyone had pressing concerns or issues. The Curriculum Planning Committee had to come up with prospective areas of study for the coming week. The members of this committee were somewhat limited since exams were coming in two weeks, and there had to be some sort of review period.I urged them to set out a review schedule that we could adopt for exams. The Teacher Liaison Committee is composed of Lester, Eric. B., Jacob and Justin, who ironically enough take up a fair bit of time. They often come to me with questions or misbehave slightly in order to get my attention. I was surprised to see that they had all chosen it as their first choice. I sat with them and they were quite excited to work with me. On one particular day, they asked me what sort of concerns I had, and I told them that it had been a pretty trying morning outside of school. They immediately told me that they would take care of it, and they turned into a mini police force who maintained control of the class. I had to sit them down and tell them that the goal of the committee was not to maintain control of the class, but to ensure communication between me and the students. The other students complained that the Liaison Committee was abusing its power. After talking to the Teacher Liaison Committee, I spoke to the class as a whole, and we had a brief discussion about how the class felt when an individual abused his power. The Teacher Liaison Committee realized that it had been a bit overzealous, and quickly apologized to the class.

Once each committee had met, the students would return to their sub- 
groups to share information and decisions. This took a few minutes, and we then came back to the roundtable in order to share everything as a group. I asked each committee if it had issues it wished to raise or decisions it wished to share.

We followed with the same structure for the remainder of the week. Perhaps due to upcoming exams, the students did not seem as engaged in this phase of the project as previous ones. The Committees often decided they had nothing to do, or they would decide on something quickly so that they could return to their subgroups and get back to work. The Discipline Committee did the lion's share of the work, and this was something that came up during the final reflection. One event that stood out for the Discipline Committee occurred midway through the week. The students were very hyper and were not focused when they came into class. It took everyone close to fifteen minutes to settle down. I was not standing there asking them to be quiet, because I felt that the Classroom Management Committee and the Discipline Committee should have taken care of it. When they finally settled, I convened an emergency meeting of the Discipline Committee to deal with the issue. The committee members took a few minutes in the hall and decided that the entire class would have a detention at lunch hour. I was on duty that day, so the students volunteered to come serve their detention in the schoolyard. I was surprised, to say the least. I did not think that they would open themselves up to the ridicule that could come with such a public detention. They also volunteered to stand along the wall for the fifteen minutes that they had lost during class. It must be noted that the other grade seven classes as well as the grade eight classes made some initial snide remarks. Our class stood there and took them all without responding. I was impressed that they had imposed a moderately harsh punishment on themselves, and that all twenty students showed up on time for the detention. It is also interesting to note that the boys wasted fifteen minutes of class time, and rather than choosing to make up for that time by doing something constructive, they choose a punitive course of action. They deprived themselves of their free time but did not see that they could recoup the lost fifteen minutes by covering the material we would have covered in class. 


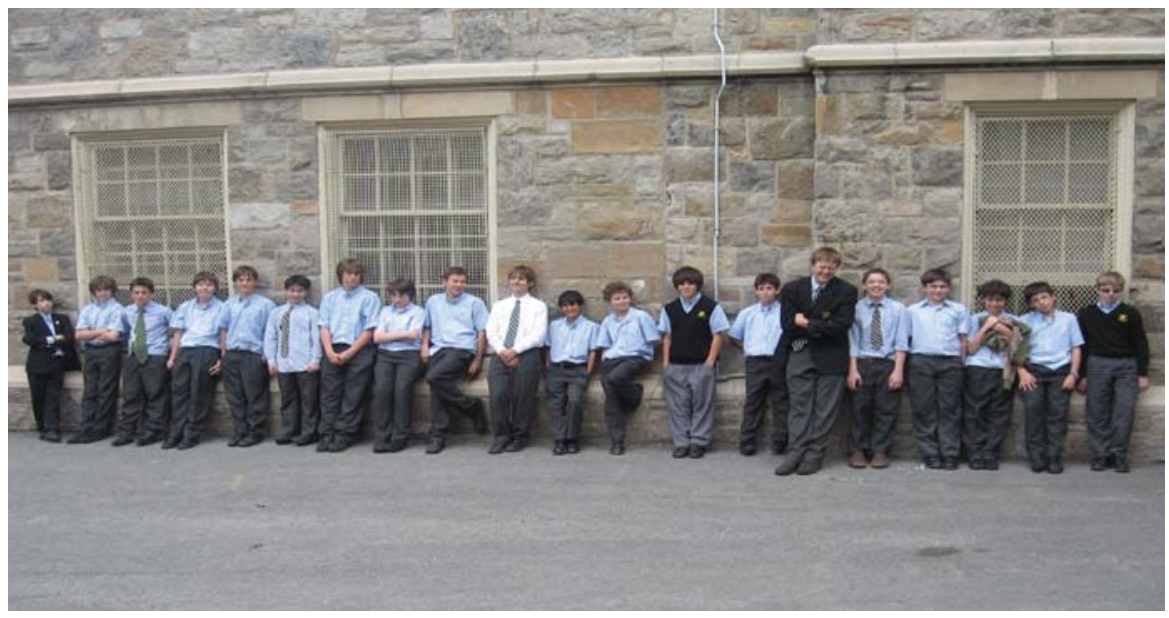

Fig. 4: Our class serving its class detention in the schoolyard

For our final roundtable discussion, the results were mixed. The bulk of the students felt that they had not contributed to the running of the class as much as they would have liked. Some felt that their committees did not have enough to do (Curriculum Planning), while others felt that they had been overworked (Discipline). Aaron said that he felt that over the long term the work load would balance out between all the committees. The students felt that with the committees in place all areas necessary for running the class had been adequately covered. They felt that should an issue arise in class, the proper committee was in place to deal with it. On the whole, in our experience the formation of committees was the least successful method of implementing a democratic classroom.

\section{Lessons Learned}

In our final debriefing session we held an initial vote about which of the three methods each student had preferred. Only one student chose the Athenian Democracy method. Four students chose the Committees, and fifteen chose the Class Council.

The Athenian Democracy method was interesting because everyone had the chance to have a say if they wanted it. However, it was far too easy for them to be shouted down or ignored by the more vocal students. There was a great deal of shouting using this method, and the quiet students were content to sit back and allow others to make the decisions for them. I am somewhat leery of this method in a class setting as it sets up the semblance of democracy but it is far too easy for the 
stronger, more vocal students to take control and steer the agenda in whatever direction they want (which is precisely what happened in Ancient Athens). The students echoed this opinion as only Eric B. chose it as the most effective method. If it were to be used in the future, speaking guidelines would have to be established so that everyone had the opportunity to speak. Ideally some sort of monitoring system would need to be in place to ensure that there is equal and fair participation. Perhaps some sort of signal is needed to allow the speaker to share his opinion, or a speaking order should be listed on the board. If those two elements could be brought in, it might prove to be an effective strategy, albeit a time-consuming one.

The strength of the Class Committees strategy came from the fact that there were five distinct committees, each of which had the mandate to deal with certain issues. If something came up, then they were able to deal with it. Over time, those committees could become well versed in their particular areas and could hopefully deal effectively with the situations that arose. Another benefit of the Class Committee strategy was that the students chose their committees. This provided them with intrinsic motivation as they were participating because they wanted to participate. In our class, the Mentoring Committee members were quite upset that there were not more students with problems as they truly wanted to help their peers. One of the negatives of the Class Committee was the time commitment needed for the students to meet with both their committees and their subgroups. Even though the time was maybe five to ten minutes more per class beyond the time allotted to the Class Council, it did add up over time. While the expertise of each student on the committee is a positive, it can also be a negative. Students can become well versed in their particular area but may be distanced from the other areas of classroom life, only hearing about them in their subgroups. The decision-making power lay completely in the hands of the respective committees. The other students were forced to trust that the committee would take their best interests to heart and make a good decision without meeting with them.

The majority of the students chose the Class Council as their preferred method. Their reasons for doing so varied. The students felt like the Council had represented their interests best, enabled them to get more things done, and got more things done within the class. They also felt that the Council got better with practice and made strong, fair decisions that benefited the class. David felt that even if you were not a member of the Council, “... you still had a say by telling your group council member. It was very effective because only five people had to decide." I am inclined to agree with those fifteen. The small groups enabled even the shyest students to speak their minds and share their opinions. 
The simple act of involving the students in the decision making allowed them to more fully engage in the class. While observing them during those six weeks, I noticed that they seemed more relaxed about the work they had to do. The underlying stress level that had plagued them for the bulk of the year seemed gone during the project. The incidences of immature behavior also decreased dramatically. One has to remember that these are grade seven boys who attend an all-boys school. They can be immature and rambunctious at times, both in and out of class. This type of behavior almost vanished within the class, and I think this was due to the increased level of responsibility they felt. I was no longer the only one making the decisions and imposing consequences. They were now responsible for their own behavior and the monitoring of it.

I also noted a greater degree of academic success during the project. This was a positive by-product of the democratic classroom environment. I was looking to have the students take on more responsibility for their behavior and engagement in school, and the fact that their academic results improved demonstrated that they were feeling good about the way their class was being run. They were engaged with the subject matter due to a greater feeling of ownership. The poetry anthologies the boys produced were meticulously assembled and were well illustrated. The students took great pride in showing them off to each other before submitting them. Would this have happened anyway? Possibly. While the students were all quite able, we had not experienced such a high degree of success as a class before. I cannot prove definitively that the democratic classroom had a positive effect on the boys' engagement in school, but from what I observed I would say it did. The positive looks on their faces, the enthusiastic way they came into class, the excitement they shared during discussions, and the success they experienced as a class all lead me to conclude that sharing the decision-making power with our students can only serve to help them be better students and better citizens in the long run. 


\section{Notes}

1. "The Pygmalion effect, or Rosenthal effect, refers to situations in which students perform better than other students simply because they are expected to do so." For source and more information:http://en.wikipedia.org/wiki/Pygmalion_effect.

2. Since it is an all-boys school, the pronoun "he" is used throughout the text.

3. Pseudonyms have been used to protect the identity of the participants.

\section{References}

Brodhagen, B. L. (1995). The situation made us special. In M. W. Apple \& J. A. Beane (Eds.), Democratic schools (pp. 83-100). Alexandria: Association for Supervision and Curriculum Development.

Dalin, P., \& Rust, V. (1996). Toward schooling for the twenty-first century. London: Redwood Books.

de los Reyes, E., \& Gozemba, P. (2002). Pockets of hope: How students and teachers change the world. Westport: Bergin and Garvey.

Giroux, H. (1993). Living dangerously. New York: Peter Lang.
Osborne, K. (2001). Democracy, democratic citizenship, and education. In J. R. Portelli \& R. P. Solomon (Eds.), The erosion of democracy in education: From critique to possibilities (pp. 29-62). Calgary: Detselig Enterprises Ltd.

Rothstein, S. (1996). Schools and society: New perspectives in American education. New Jersey: Merrill.

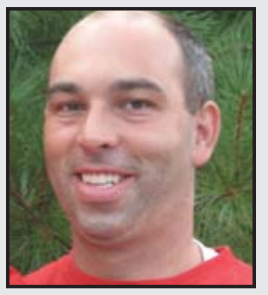

Matthew McCarney graduated from Bishop's University in 1997 with a Bachelor of Arts, and in 1998 with a Bachelor of Education degree. He later earned a Master of Arts in Educational Leadership from McGill University (2008). A teacher for the past eleven years, he has taught in both public and private schools as well as in Japan. He is currently the English and History department head at Selwyn House School in Montreal. 